\title{
Distributive judgments in cooperative production contexts
}

\section{Julgamentos distributivos em contextos cooperativos de produção}

\author{
Guilherme Ribeiro Eulalio CABRAL ${ }^{1}$ iD 0000-0003-4487-6824 \\ Leonardo Rodrigues SAMPAIO² ID 0000-0003-2383-4094 \\ Antonio ROAZZI ${ }^{1}$ iD 0000-0001-6411-2763
}

\begin{abstract}
The objective of the present study was to investigate distributive judgments in hypothetical situations involving productive activities. The participants should divide produced cupcakes between two story characters. One of the characters was the participant him/herself. Three factors were analyzed: (1) mode of production: cooperative with the help of one person or alone using someone else's means of production; (2) purpose of production: sale or picnic; and (3) participants' perspective: give the cupcakes to or take from the other character. Their confidence on each judgment and how easily they made their judgments were other aspects analyzed. The sample consisted of 156 university students. The results showed that the three factors influenced the participants' distributive judgment, and mode of production had the most significant influence. These results were discussed based on recent research on cooperative behavior and cognitive mechanisms that affect the decision-making process in situations involving distributive justice.
\end{abstract}

Keywords: Cooperation; Decision making; Distributive justice; Ownership.

\section{Resumo}

O presente estudo teve como objetivo investigar julgamentos distributivos em situações hipotéticas envolvendo atividades produtivas. Os participantes deveriam dividir os bolinhos produzidos entre dois personagens, um dos quais identificado

\footnotetext{
$\nabla \nabla v$

1 Universidade Federal de Pernambuco, Programa de Pós-Graduação em Psicologia Cognitiva. Av. Acadêmico Hélio Ramos, s/n., $8^{\circ}$ andar, Cidade Universitária, 50740-550, Recife, PE, Brasil. Correspondência para/Correspondence to: G.R.E. CABRAL. E-mail: <grecabral@gmail.com>.

2 Universidade Federal do Vale do São Francisco, Colegiado de Psicologia. Petrolina, PE, Brasil.

Article based on the dissertation of G.R.E. CABRAL, entitled "Julgamento distributivo em contextos de trabalho cooperativo e de uso de propriedade". Universidade Federal de Pernambuco, 2015.

Support: Coordenação de Aperfeiçoamento de Pessoal de Nível Superior.

$\checkmark \nabla \mathbf{v}$

Como citar este artigo/How to cite this article

Cabral, G. R. E., Sampaio, L. R., \& Roazzi, A. (2018). Distributive judgments in cooperative production contexts. Estudos de Psicologia (Campinas), 35(2), 205-215. http://dx.doi.org/10.1590/1982-02752018000200009
} 
como o próprio participante. Foram analisados três fatores: (1) modo de produção: cooperativo com ajuda de uma pessoa ou sozinho, usando os meios de produção de outro; (2) finalidade da produção: venda ou piquenique; e (3) perspectiva do participante: dar os bolinhos para o outro ou pegar para si. Também foram medidas a facilidade e a confiança em cada julgamento. A amostra foi composta de 156 estudantes universitários. Os resultados indicaram que os três fatores influenciaram o julgamento distributivo dos participantes, sendo o modo de produção o mais relevante. Esses resultados foram discutidos à luz de pesquisas recentes sobre o comportamento cooperativo e os mecanismos cognitivos que influenciam o processo de tomada de decisão em questões envolvendo a justiça distributiva.

Palavras-chave: Cooperação; Tomada de decisão; Justiça distributiva; Propriedade.

One of the most prevalent and important forms of cooperation among humans is the production of goods, which results in the need for making decisions about how to distribute them later (Moll \& Tomasello, 2007). Therefore, evaluating people's judgment about the distribution of goods produced collaboratively is essential for a deeper understanding of the role of productive activities in distributive justice.

Recent studies have shown that distributive judgments and actual distribution behaviors are closely associated with the high level of social cooperation among humans (Moll \& Tomasello, 2007; Tomasello \& Vaish, 2013). More specifically, it has been demonstrated that children as young as three years of age have a tendency to share most equally the rewards resulting from a collaborative effort, even when they have the opportunity to keep everything for themselves (Warneken, Lohse, Melis, \& Tomasello, 2011). On the other hand, when they are in a situation where they work individually on the same task and with the same results, this egalitarian sharing tendency is not displayed. In addition, the egalitarian distribution of rewards between people is more likely to happen when individuals feel they belong to the same social group (Tomasello \& Warneken, 2008), which usually occurs when working in collaboration with each other. Thus, cooperative work can promote the decision-making necessary in different cognitive processes involved in social relations.

With regard to distributive judgment in cooperative contexts, Konow (1996, 2001) presented three basic justice principles that are used by individuals to decide whether a distribution is fair or not, based on the accountability principle, i.e., an distribution; the major element of this principle is the effort undertaken. Thus, if two people produce different quantities of a particular good, it would be fair if each person's entitlement were proportional and equal to his contribution. However, exogenous factors should be considered for the fair distribution of the resources produced. For example, one cannot demand the same level of productivity from a person who has a motor impairment that affects his or her work and from a person with normal movement capacity. In addition, the personal energy expenditure to perform a task has to be disregarded to avoid penalizing the person who needs to spend more energy to perform the same task. Thus, each person is responsible for the factors that can be controlled, but external factors that interfere with individual productivity also need to be considered to ensure fair distribution of available resources.

Two other factors may conflict with the accountability principle, according to Konow (1996, 2001): the principles of efficiency and needs. The principle of efficiency alone does not define whether a distribution is fair, but it can affect it, making it more or less fair. With regard to the needs principle, distributions in which the person whose need is greatest is favored tend to be seen as more fair distributions, even if this implies a smaller amount for the one who has produced more. Konow states that these three distributive principles would not apply to specific contexts, i.e., it is not the context that determines which principles to use but the important information that underlies decision-making.

The topic of distributive justice has also been studied in work contexts from a motivational point of view (Haar \& Spell, 2009), as well as in terms of the influence of feeling ownership on productive 
structures in organizations (Pierce \& Jussila, 2010; Pierce, O'Driscoll, \& Coghlan, 2004).

Even in experiments involving real consequences for the participants, in which self-interest was generally exacerbated, people's concern about the distribution of resources was also observed (Fehr \& Schmidt, 1999). Experiments involving economic games, such as the Dictator Game - in which one participant has full power to decide how to divide the resource -, demonstrate that people give valuable resources to each other, even when they have the opportunity to keep everything for themselves (Engel, 2011).

Another economic game widely used to evaluate distributive decisions among people is the Ultimatum Game. In this game, the participant who receives a sum of money makes a proposal to the other player regarding how to divide the money between them. The other player can decide between accepting or rejecting the proposal; in case of rejection, both players receive zero. The results of empirical studies in which this game was used have shown that people are willing to reject receiving a certain amount of money when they consider that there was an unfair division (Charness \& Gneezy, 2008).

Despite their widespread use in several areas of knowledge, some authors point to the overly abstract nature of economic games and suggest that the experiments using such games should provide enough information for the participants to respond based on their everyday experience (Baumard, Boyer, \& Sperber, 2010; Eckel \& Grossman, 1996). This would prevent people from filling the information gaps related the context of distribution based on personal or contextual biases (inferences, attributions of causality, accountability, etc.), reducing the impact on the experimental results (Konow, 2001).

Another aspect to be considered when distributing resources is the feeling of ownership of the assets that will be distributed. Due to the effort made towards achieving an outcome, the individual may feel more deserving than others, which could lead to a tendency to refrain from sharing the resource with others (Oxoby \& Spraggon, 2008).
Previous studies have shown that ownership enables its owner to decide on the usufruct of his/her resources, and the investment made on an object is an important aspect in establishing who owns it and how people are related to it (Neary, Van de Vondervoort, \& Friedman, 2012). In addition, creative work exerts influence on ownership attribution and transfer (Kanngiesser, Gjersoe, \& Hood, 2010; Kanngiesser \& Hood, 2014).

The issues discussed so far show that people are concerned about the fair distribution of resources and that the distributive principles guide the way people judge and make distributive decisions (Sampaio, Camino, \& Roazzi, 2009). Work done in collaboration with others or individually and the feeling of ownership of the resource are important factors to be considered in the evaluation of distributive justice. However, to the best of our knowledge, there is no study investigating the effects of the use of ownership in a productive activity - whether in the form of raw material or means of production -, on people's distributive judgments.

Moreover, we believe that there are no empirical studies available taking into account the constituent elements of a production environment in investigations related to distributive justice. That is, studies that seek to understand how people evaluate justice by distributing goods with someone who did not participate in their production, but whose resources (instruments, ownerships, procedures etc.) were essential for the production of the good. Therefore, the present study was carried out seeking to fill these empirical and theoretical gaps.

\section{Method}

\section{Participants}

A total of 156 university students from Pernambuco, Brazil (71 men and 85 women), aged $18-46$ years $(M=20.8, D P=3.2)$ participated in this study. Of these 156 participant students, 33.0\% attended public institutions and $67.0 \%$ attended 
private institutions, 44.9\% were enrolled in courses in Humanities and Social Sciences (Psychology, Administration, etc.), and $55.1 \%$ were enrolled in courses in Health and Exact Sciences (Pharmacy, Nursing, Engineering etc.).

\section{Instruments}

Data were collected using a socio-demographic questionnaire and some fictitious stories, and both were designed using the online form builder LimeSurvey. The stories portrayed the collaborative production of some goods and had two characters. Each story was presented in comic-strip format to facilitate reading.

\section{Experimental Design}

In order to evaluate the distributive judgment of the participants, eight hypothetical stories were created, in which two characters (one of them was the participant him/herself) were involved in the production of cupcakes. The experiment is a $2 \times 2 \times 2$ factorial design with three conditions: the "purpose" of the production of the cupcakes (sale or picnic); the "mode" of production of the cupcakes (whether they were made with the help of a person or using a machine - means of production owned by a different person); and each participant's "perspective" of his/her role in the stories (when giving cupcakes to or taking from the other character). In addition to these stories, the participants read a control story, in which the purpose was not defined and the character worked alone without the use of a machine.

In each story, 20 cupcakes should be divided, and the distributive judgments were evaluated based on the number of cupcakes the participants gave the characters and those they took from the characters for themselves.

\section{Procedures}

The link to the online tool was sent to the participants, who answered the questions informed consent form explaining the research, and after accepting to participate, the participants were instructed to answer some socio-demographic questions.

After this first step, the stimulus stories were presented to the participants who answered three questions related to: (1) how many cupcakes each character should receive, (2) how easily they answered the question, and (3) the confidence level on each answer given. The control story was always presented first in order to familiarize the participants with the task and prepare them for the subsequent questions. The order of presentation of the eight stories was randomly selected by the online tool used.

\section{Results}

The results show that the highest average percentage of cupcakes gave to the second character was observed in the story in which the cupcakes were made with the help of another person and would be taken to a picnic (41.5\%). On the other hand, the lowest average percentage of cupcakes was observed in the story in which the participant took the cupcakes from someone who had used his/her machine to sell them (16.7\%) (Table 1).

In order to detect the effects of each factor on the distributive judgments, a three-way repeated measures multivariate analysis of variance was carried out, in which the dependent variable was the number of cupcakes distributed. The results showed that a significant main effect for "purpose" $\left(F_{(1,154)}=11.4, p<0.001, \eta^{2}=0.07\right)$, and the participants gave a higher average percentage of cupcakes to the other characters when the purpose of the production was to take the cupcakes to a picnic $(30.7 \%)$ than when the purpose was to sell the cupcakes (27.9\%).

A significant main effect was also found for "mode of production" $\left(F_{(1,154)}=161.7, p<0.001\right.$, $\left.\eta^{2}=0.51\right)$; the participants distributed the cupcakes more evenly when they worked with another person $(35.8 \%)$ than when they used someone 
Mean percentage and standard deviations of the cupcakes distributed in each story

\begin{tabular}{|c|c|c|c|c|c|}
\hline \multicolumn{2}{|c|}{ Experimental Conditions } & \multicolumn{4}{|c|}{ Cupcake production mode } \\
\hline \multirow{2}{*}{ Purpose } & \multirow{2}{*}{ Perspective } & \multicolumn{2}{|c|}{ Person } & \multicolumn{2}{|c|}{ Machine } \\
\hline & & Mean (\%) & $S D$ & Mean (\%) & $S D$ \\
\hline \multirow[t]{2}{*}{ Sale } & Give & 38.7 & 17.29 & 26.4 & 16.53 \\
\hline & Take & 31.4 & 21.47 & 16.7 & 17.70 \\
\hline \multirow[t]{2}{*}{ Picnic } & Give & 41.5 & 15.60 & 29.2 & 16.91 \\
\hline & Take & 32.9 & 19.46 & 20.4 & 19.67 \\
\hline
\end{tabular}

else's machine (22.8\%), even if they produced the same amount of cupcakes. Finally, a significant main effect of the participant's "perspective" $\left(F_{(1,154)}=70.7, p<0.001, \eta^{2}=0.31\right)$ was observed since they gave more cupcakes (33.6\%) than they took for themselves (25.0\%). On the other hand, there was no significant interaction effect between these conditions.

The influence of socio-demographic variables on the dependent variable was also assessed, but there was no significant effect of $\operatorname{sex}\left(F_{(1,154)}=1.36\right.$, $p=0.25)$, course - students enrolled in humanities courses or others $\left(F_{(1,154)}=0.29, p=0.59\right)$, or the type of educational institution - public or private $\left(F_{(1,154)}=3.3, p=0.072\right)$.

With respect to how easily the participants made the distributive judgments, the main effects were observed for the factor Purpose of distribution $\left(F_{(1,155)}=8.34, p=0.004, \eta^{2}=0.051\right)$ and for the factor Help $\left(F_{(1,155)}=11.8, p=0.001, \eta^{2}=0.071\right)$. An interaction effect was found between the factors Help and Perspective $(F(1,155)=6.5, p=0.012$, $\left.\eta^{2}=0.04\right)$. More specifically, it was easier to answer in contexts where work was done by two people than when one person worked using someone else's machine. Furthermore, situations involving the distribution of cupcakes for picnics were easier to resolve than those involving distributions of cupcakes for sale.

Personal confidence on the distribution showed similar results to those of the main effects of the factor Purpose $\left(F_{(1,155)}=7.78, p=0.006\right.$, $\left.\eta^{2}=0.048\right)$ and the factor Help $\left(F_{(1,155)}=10.8\right.$, $\left.p=0.002, \eta^{2}=0.061\right)$. There was an interaction effect between the factors Help and Perspective
$\left(F_{(1,155)}=5.9, p=0.016, \eta^{2}=0.04\right)$. Similarly to what was found in terms of how easily the participants made the distributive judgments, the contexts of work involving two people showed higher level of confidence when compared to the use of someone else's machine. Moreover, the distributions of the cupcakes that would be taken to the picnic were made with a higher confidence level than when the cupcakes would be sold.

These results indicated a high degree of association between the degrees of ease and the confidence levels on the decisions, justifying the creation of a single measure representing the level of conflict in the distributions, based on the sum of the scores obtained in these two scales. This measure resulted in an eight-point grading scale, in which 1 represented the highest degree of conflict, and 8 represented the lowest degree of conflict in making distributive judgments.

In order to evaluate the association between the amounts of cupcakes distributed in each situation and this conflict scale, correlation analyses were carried out, and the results are shown in Table 2.

In general, these correlations indicate that the more they gave to the other character, the less conflictive the judgment was because the negative coefficients were found for the participants' perspective on taking the cupcakes, that is, the less they took for themselves, the smaller the conflict created. It is worth noting that in the cases in which there was help from another person, this relationship did not reverse in terms of the perspective on taking the cupcakes. 
Correlations between distribution and degree of conflict in making judgments, according to the experimental conditions used

\begin{tabular}{|c|c|c|c|c|c|c|c|c|}
\hline \multirow{3}{*}{$\begin{array}{l}\text { Mode of production } \\
\text { Amount }^{*}\end{array}$} & \multicolumn{4}{|c|}{ Sale } & \multicolumn{4}{|c|}{ Picnic } \\
\hline & \multicolumn{2}{|c|}{ Give } & \multicolumn{2}{|c|}{ Take } & \multicolumn{2}{|c|}{ Give } & \multicolumn{2}{|c|}{ Take } \\
\hline & $r$ & $p$ & $r$ & $p$ & $r$ & $p$ & r & $p$ \\
\hline Person & 0.19 & 0.021 & 0.2 & 0.012 & 0.24 & 0.002 & 0.01 & 0.90 \\
\hline Machine & 0.2 & 0.011 & -0.19 & 0.016 & 0.02 & 0.8 & -0.19 & 0.016 \\
\hline Equality $^{* *}$ & $r_{p b}$ & $p$ & $r_{p b}$ & $p$ & $r_{p b}$ & $p$ & $r_{p b}$ & $p$ \\
\hline Person & 0.35 & 0.001 & 0.35 & 0.001 & 0.36 & 0.001 & 0.15 & 0.07 \\
\hline Machine & 0.25 & 0.002 & 0.004 & 0.96 & 0.24 & 0.03 & 0.07 & 0.40 \\
\hline
\end{tabular}

Note: "Distributed amounts (Pearson correlation); ${ }^{* *}$ Egalitarian or non-egalitarian distribution (Point-biserial correlation).

This result led to the desire to deepen the understanding of these correlations. Thus, the distributions were classified into two types: egalitarian (when $50 \%$ of the cupcakes were given or taken) and non-egalitarian (all other cases). The objective was to verify whether the amount distributed per se had the same degree of importance as the justice principle of egalitarian distribution as a broader and more general pattern than the amount given in each experimental situation. As can be seen in Table 2, the correlations were stronger when considering the type of distribution instead of the amount distributed. In addition, there was a change in the pattern of some significant correlations when compared with those in previous analysis.

More specifically, in terms of the perspective on taking the cupcakes, there was no significant correlation between the egalitarian distribution and the degree of conflict in making judgments, except for cases of production using someone else's machine. However, this may have occurred because of the low percentage of egalitarian distribution in these cases, which was lower than $20 \%$, while in cases of production with collaboration of another person, the percentage was always higher than $45 \%$.

\section{Discussion}

The present study evaluated distributive 210 judgments in productive contexts based on the analysis of the influence of two main factors: the use of someone else's property and the effort put into the production of cupcakes. The results showed that, in general, these two factors were important in the participants' distributive judgments. On the other hand, there were no significant effects of the variables sex, type of educational institution, or course on the participants' distributive decisions.

As for the effect of the work on the distribution of resources, the results obtained corroborate those reported in other studies which have shown that the work done is fundamental in the division of resources, and it is widely used even among very young children (Hamann, Warneken, Greenberg, \& Tomasello, 2011; Tomasello \& Warneken, 2008; Warneken et al., 2011). However, no studies were found in the literature contrasting these effects with other modes of production of goods, especially comparing the work done and the use of means of production.

The association between labor effort and means of production deserves attention, mainly, in a society whose production system is based on Capitalism. Means of production have emerged specifically to serve as a workforce, replacing, in part, the effort made by people to carry out some productive activity in a wide variety of areas. Machines have replaced workers in many factories, and they are seen as labor sellers and are reckoned as human capital. Therefore, an activity in which two people worked to produce a certain amount of goods could be carried out by one person only using a machine. 
The results show that the characters who participated in the production were rewarded with a greater amount of resource than those who did not participated in the production but only lent their machine for the production of cupcakes, even if there was equality in the production efficiency, i.e., in the final quantitative result of production. However, it is not clear whether this greater reward for the work done is due to a greater amount of resources given to the other character, or it is due to a greater number of egalitarian distributions made in the collaborative working condition. The results showed that more than half of the participants divided the resources equally between the two story characters in the collaborative working condition (Figure 1), increasing the total average of the distributions in this condition. Thus, the choice for a distributive principle, egalitarian in this case, may have led to an indirect favoring of the other character.

This result finds partial support in the literature since in a previous study involving children, Sampaio and Cabral (2015) demonstrated that children often make distributions with the idea of using distributive principles, but they cannot always be accurate when converting these principles into amounts of goods. This also contributes to the understanding of the results that show that egalitarian distributions were less conflicting among the participants. This can be related to social heuristics that influence decisions regarding cooperative behaviors (Evans, Dillon, \& Rand, 2015; Nishi, Christakis, Evans, O’Malley, \& Rand, 2016; Rand, Greene, \& Nowak, 2012;).

However, there was association only between the egalitarian distributions and the degree of conflict in the decision, regarding the condition in which participants took the resources in one of the four existing scenarios. The distribution of resources based on taking something for themselves or giving something to others can result in different distributed amounts (Korenok, Millner, \& Razzolini, 2014), as shown in the results of this study. However, investigating a real situation of donation to a charity, Grossman and Eckel (2015) found no difference between these two types of distribution. The experimental conditions in the

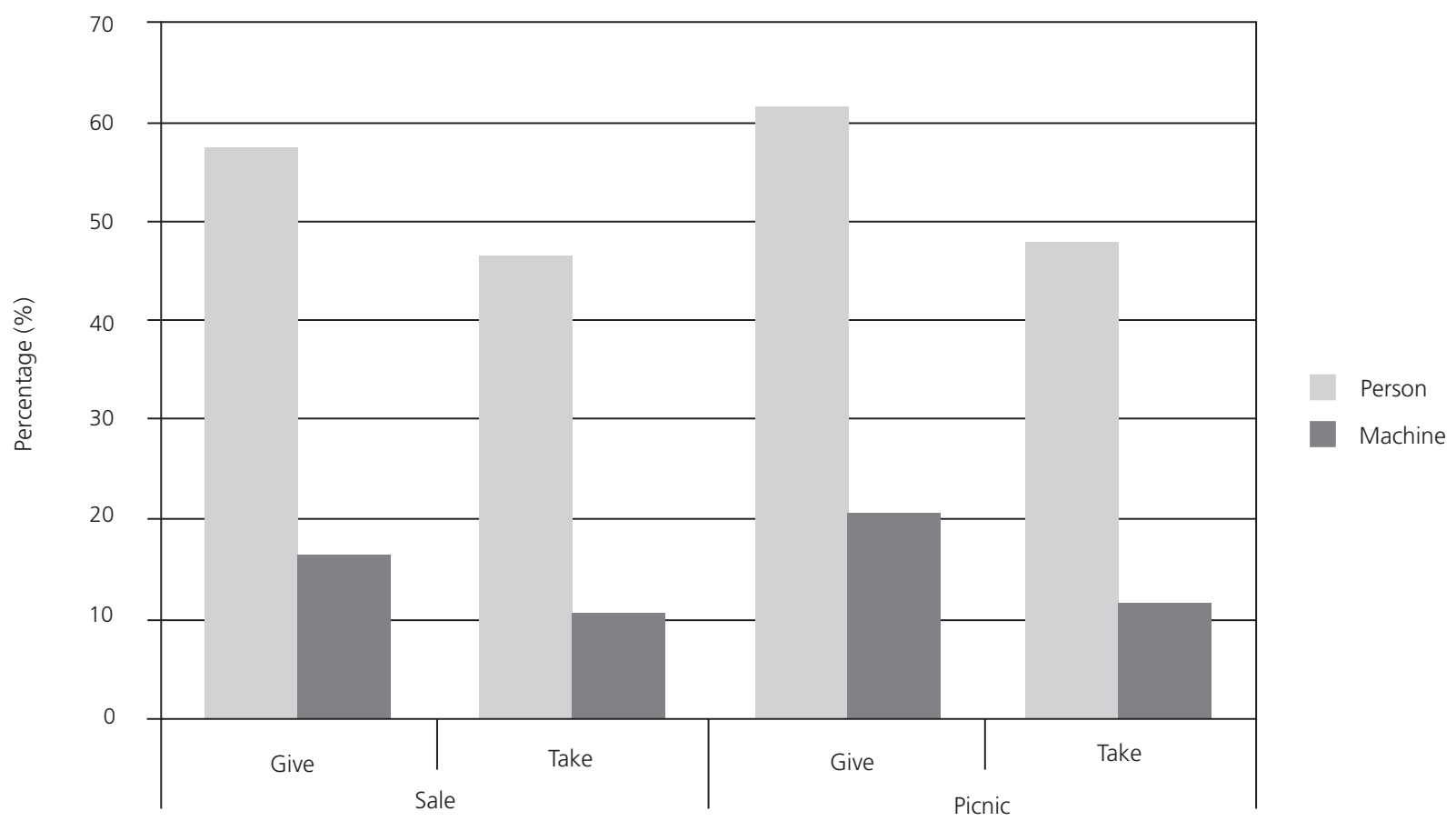

Figure 1

Percentage of egalitarian distributions by experimental conditions. 
present study were related to common real-world contexts; however, there were no real consequences for the participants, which may have represented an abstract situation even though they were informed about the productive activity and the purpose of the production. This may have led to a greater variability in the motivations expressed by the participants in the stories comparing the situation in which the distributions were based on taking the cupcakes with that in which they were based on giving the cupcakes since taking something from others can be related to a non-cooperative attitude, contrasting to the cooperative nature of the activities in the stories (Vogelsang \& Tomasello, 2016). For these reasons, the egalitarian distribution shown when taking the resources from the other character may have been easier for some participants than others.

It is possible to explain the greater amount of resources given to the character directly involved in the production than to the one who owned the machine based on accountability in the result of the activity carried out by people, as proposed by Konow (1999, 2001). Although the means of production can increase efficiency, it must be operated by a person. Thus, the fact that someone owns a machine that facilitates the work would not hold this person accountable for the manufactured product. This hypothesis would be in agreement with the proposal of Konow (2001) - experiments $2 \mathrm{~A}, 2 \mathrm{~B}$, and $2 \mathrm{C}$ - because, in this case, the recognition of the contribution of the increased efficiency by enabling one person to do the work of two people would not be more important than the personal responsibility of those directly involved in the task.

On the other hand, it can be considered that working together promotes equal sharing of resources, as observed in children at young age (Warneken et al., 2011). This may indicate that not only the work done would be more valued, but it would also lead to different distributive judgments when people produce together.

Both purpose and participants' perspective influenced resource division decisions. In the first case, which refers to what would be done with the resources, when the purpose was sale, less cupcakes were given to the other character than when the purpose was taking the cupcakes to a picnic.

Two considerations arise from these findings: the sale of the cupcakes can be interpreted as a source of livelihood, which is different from the situation when the cupcakes are taken to a picnic, a leisure or entertainment activity, without impacting earnings. Thus, it is possible to consider that the character who intended to sell the cupcakes supposedly would need more the gains resulting from the sale than the character who would only take cupcakes to a picnic; this would induce the participants to use a principle based on their needs during the division of the cupcakes.

On the other hand, sharing cupcakes in a picnic implies that they would be split between people related to the character, such as friends, co-workers, or even family members. This could entail a tendency to want to keep more cupcakes to promote greater well-being of those who are close to them or belong to their circle of friends.

Based on these interpretations, the results indicate that the participants seem to have used the principle of needs to make their judgments since they considered that the character who would sell the cupcakes should have more units because the purpose is related to the generation of income that could be used to pay for the character's living expenses.

As for the second factor analyzed - participants' perspective -, Skarzynska (1989) showed that the assessment of the degree of fairness of a particular distribution tends to vary if an individual is in the position of an external observer (not involved) or of an actor (the consequences of the distribution will directly affect him). However, in the present study, both characters are in the position of an actor, but they have "opposing" roles in terms of the distribution consequences.

There are also two possible interpretations for the results obtained: the participants may have considered achieving higher gains for themselves, which would result in fewer cupcakes left for the second character, or the participants could have put themselves in the position of having to take 
something from someone else. In this case, when asked about how many cupcakes they would take for themselves, there would be an association with subtracting quantities instead of adding when giving something to someone else. Moreover, it can be considered that there is more respect for the right to possess the cupcakes when someone requested to take something from someone else.

The results showed that less cupcakes were taken than given, which is in agreement with the results reported in the study of Korenok et al. (2014), carried out in a specific distribution context. Since in the present study there was a situation involving the production of goods, it was considered that when the participants were in the position of giving the resources they felt more like the owners of the cupcakes than when they were asked to take the cupcakes, making it easier to transfer ownership of the cupcakes to the other character. This may have reduced the tendency to take more cupcakes for themselves when they needed to take them from the character that was in possession of the cupcakes. Therefore, it can be said the participants showed respect for the possessions of others, which made them feel they had less right to take than to give something.

This interpretation is in line with the study carried out by Oxoby and Spraggon (2008), who found a tendency not to give a resource when it is perceived it as their own possession since this feeling of ownership may be influenced by the role or position that people occupy.

\section{Final Considerations}

The present study addressed a topic that has been little investigated in Psychology although it is has been widely discussed in other areas such as sociology and economics. The data obtained show that the work has a central importance in the issue of making judgments about the distribution of resources, predominating over the means of production, at least in the case of a sample of university students in Northeastern Brazil. It is worth highlighting the great number of egalitarian distributions when collaborative work was done.
This may have occurred because when work is done in collaboration with another person, it may imply in a different distributive judgment, in which instead of deciding specifically upon exact quantities, one decides based on a principle of division, such as equality, for example.

Therefore, there is a greater recognition of the contribution of the work done by another person than of the contribution related to the loan of a machine. A future study could investigate a different situation, in which instead of dividing the outcome of a collaborative production, the participants could be put in situations where they would have to choose between getting help from another person or using someone else's machine to do a job, knowing that they would have to share the production results among themselves. One possible outcome is that participants would rather use someone else's machine; perhaps because they would feel more deserving of what they have produced and could therefore keep more for themselves. On the other hand, perhaps the work done with another person would be more rewarding and offer other types of non-monetary benefits, implying a preference for working together, even if in the end the individual gets less for him/herself.

Future studies could assess the association between the type of resource used in a productive activity (means of production or raw material) and the sense of ownership or possession of this resource, for example, the impossibility of reusing a raw material can attribute a higher intrinsic value to it. It should also be considered that the use of the means of production (which could be used again) might have been seen as a loan in which the financial relationship would be less important thus reducing the need to reward for its use.

It should also be considered that there were correlations between distributive principles and the degree of conflict in making the decisions although the experiment was not designed considering this hypothesis. Other experiments focusing on this finding can be carried out to test this hypothesis directly, aiming at achieving more robust results. This is in accordance with the recent interest in 
investigating the association among cooperative behavior, reaction time, and decision-making conflict (Rand et al., 2012; Evans et al., 2015; Nishi et al., 2016).

Finally, some limitations of this study are highlighted below. First, all distributions analyzed were based on hypothetical situations, which may be different from the distributive behavior when there is has a real consequence of the decision made (Blake, McAuliffe, \& Warneken, 2014). Furthermore, the only fairness criterion was the amount given. However, distribution fairness could have been assessed differently, for example evaluating how fair they were (Shye, 2014) or whether different distributions would be fair (Konow, 2001). Another possibility would be to ask participants to justify why those amounts were distributed in that way.

\section{Contributors}

All authors made substantial contributions to the conception and design of this study, to data analysis and interpretation, and to the revision and approval of the final version.

\section{References}

Baumard, N., Boyer, P., \& Sperber, D. (2010). Evolution of fairness: Cultural variability. Science, 23(329), 388-389. http://dx.doi.org/10.1126/science.329.5990. $389-a$

Blake, P. R., McAuliffe, K., \& Warneken, F. (2014). The developmental origins of fairness: The knowledgebehavior gap. Trends in Cognitive Sciences, 18(11), 559-561. http://dx.doi.org/10.1016/j.tics.2014.08.003

Charness, G., \& Gneezy, U. (2008). What's in a name? Anonymity and social distance in dictator and ultimatum games. Journal of Economic Behavior and Organization, 68(1), 29-35. http://dx.doi. org/10.1016/j.jebo.2008.03.001

Eckel, C., \& Grossman, P. (1996). Altruism in anonymous dictator games. Games and Economic Behavior, 16(2), 181-191. http://dx.doi.org/10.1006/game.1996.0081

Engel, C. (2011). Dictator games: A meta study. Experimental Economics, 14(4), 583-610. http://dx.doi. org/10.1007/s10683-011-9283-7

Evans, A. M., Dillon, K. D., \& Rand, D. G. (2015). Fast but not intuitive, slow but not reflective: Decision conflict drives reaction times in social dilemmas. Journal of
Experimental Psychology: General, 144(5), 951. http:// dx.doi.org/10.1037/xge0000107

Fehr, E., \& Schmidt, K. (1999). A theory of fairness, competition and cooperation. Quarterly Journal of Economics, 114(3), 817-868. http://dx.doi.org/10.11 $62 / 003355399556151$

Grossman, P. J., \& Eckel, C. C. (2015). Giving versus taking for a cause. Economics Letters, 132, 28-30. http:// dx.doi.org/10.1016/j.econlet.2015.04.002

Haar, J., \& Spell, C. (2009). How does distributive justice affect work attitudes? The moderating effects of autonomy. The International Journal of Human Resource Management, 20(8), 1827-1842. http:// dx.doi.org/10.1080/09585190903087248

Hamann, K., Warneken, F., Greenberg, J., \& Tomasello, M. (2011). Collaboration encourages equal sharing in children but not chimpanzees. Nature, 476, 328-331. http://dx.doi.org/10.1038/nature10278

Kanngiesser, P., \& Hood, B. M. (2014). Young children's understanding of ownership rights for newly made objects. Cognitive Development, 29, 30-40. http:// dx.doi.org/10.1016/j.cogdev.2013.09.003

Kanngiesser, P., Gjersoe, N. L., \& Hood, B. M. (2010). The effect of creative labor on propertyownership transfer by preschool children and adults. Psychological Science, 21(9), 1236-1241. http://dx.doi. org/10.1177/0956797610380701

Konow, J. (1996). A positive theory of economic fairness. Journal of Economic Behavior and Organization, 31(1), 13-35. http://dx.doi.org/10.1016/S0167-2681 (96)00862-1

Konow, J. (2001). Fair and square: The four sides of distributive justice. Journal of Economic Behavior and Organization, 46(2), 137-164. http://dx.doi.org/10. 1016/ S0167-2681(01)00194-9

Korenok, O., Millner, E. L., \& Razzolini, L. (2014). Taking, giving, and impure altruism in dictator games. Experimental Economics, 17(3), 488-500. http://dx. doi. org/10.1007/s10683-013-9379-3

Moll, H., \& Tomasello, M. (2007). Co-operation and human cognition: The Vygotskian intelligence hypothesis. Philosophical Transactions of the Royal Society, 362(1480), 639-648. http://dx.doi.org/10.1098/ rstb.2006.2000

Neary, K. R., Van de Vondervoort, J. W., \& Friedman, O. (2012). Artifacts and natural kinds: Children's judgments about whether objects are owned. Developmental Psychology, 48(1), 149-158. http:// dx.doi.org/10.1037/a0025661

Nishi, A., Christakis, N. A., Evans, A. M., O'Malley, A. J., \& Rand, D. G. (2016). Social environment shapes the speed of cooperation. Scientific Reports, 6, 29622. http://dx.doi.org/10.1038/srep29622

Oxoby, R. J., \& Spraggon, J. M. (2008). Mine and yours: Property rights in dictator games. Journal of Economic 
Behavior and Organization, 65(3-4), 703-713. http:// dx.doi.org/10.1016/j.jebo.2005.12.006

Pierce, J., \& Jussila, I. (2010). Collective psychological ownership within the work and organizational context: Construct introduction and elaboration. Journal of Organizational Behavior, 31(6), 810-834. http://dx.doi. org/10.1002/job.628

Pierce, J., O'Driscoll, M., \& Coghlan, A. (2004). Work environment structure and psychological ownership: The mediating effects of control. The Journal of Social Psychology, 144(5), 507-534. http://dx.doi. org/10.3200/SOCP.144.5.507-534

Rand, D. G., Greene, J. D., \& Nowak, M. A. (2012). Spontaneous giving and calculated greed. Nature, 489(7416), 427-430. http://dx.doi.org/10.1038/ nature 11467

Sampaio, L. R., \& Cabral, G. R. E. (2015). Differences in allocation patterns and in the use of distributive principles emerge from children of brazilian parents in Brazil and in the United States. Suma Psicológica, 22(1), 19-27. http://dx.doi.org/10.1016/ j.sumpsi.2015.05.003

Sampaio, L. R., Camino, C. P. S., \& Roazzi, A. (2009). Justiça distributiva: uma revisão da literatura psicossocial e desenvolvimentista. Psicologia em Estudo (Maringá), 14(4), 631-640. http://dx.doi.org/10.1590/S1413-73 722009000400003

Shye, S. (2014). Faceted Action System Theory (FAST). In A. C. Michalos (Ed.), Encyclopedia of Quality of Life and Well-Being Research (pp.2119-2125). Dordrecht: Springer. http://dx.doi.org/10.1007/978-94-007-07 53-5_3616

Skarzynska, K. (1989). Evaluative perspective and distributive justice. In N. Eisenberg, J. Roykowsky, \& E. Staub (Orgs.), Social and moral values: Individual and societal perspectives (pp.139-152). Hillsdale: Lawrence Erlbaum.

Tomasello, M., \& Vaish, A. (2013). Origins of human cooperation and morality. Annual Review of Psychology, 64(1), 231-255. http://dx.doi.org/10.1146/ annurev-psych-113011-143812

Tomasello, M., \& Warneken, F. (2008). Share and share alike. Nature, 454, 1057-1058. http:/dx.doi. org/10.1038/4541057a

Vogelsang, M., \& Tomasello, M. (2016). Giving is nicer than taking: Preschoolers reciprocate based on the social intentions of the distributor. PloS One, 11(1), e0147539. http://dx.doi.org/10.1371/journal. pone.0147539

Warneken, F., Lohse, K., Melis, A., \& Tomasello, M. (2011). Young children share the spoils after collaboration. Psychological Science, 22(2), 267-73. http://dx.doi. org/10.1177/0956797610395392

Received: November 11, 2016

Final version: April 7, 2017

Approved: April 24, 2017 